\title{
振幅依存性を考慮した中低層 R C, S R C 造建物の水平 1 次振動特性 STUDY ON HORIZONTAL FIRST MODE VIBRATION CHARACTERISTICS OF LOW AND
MIDDLE RISED RC AND SRC BUILDINGS CONSIDERING AMPLITUDE DEPENDENCY
}

中村尚弘 ${ }^{* 1}$, 鹿嶋俊英 ${ }^{2}$, 木下拓也*3, 伊藤 真二*4,

宮本泰志 ${ }^{* 5}$, 曽根孝行 ${ }^{* 6}$, 荏本孝久 ${ }^{* 7}$, 犬伏徹志 ${ }^{* 8}$

Naohiro NAKAMURA, Toshihide KASHIMA, Takuya KINOSHITA, Shinji ITO, Yasushi MIYAMOTO, Takayuki SONE, Takahisa ENOMOTO and Tetsushi INUBUSHI

\begin{abstract}
Since it is well known that the vibration characteristics such as the eigenperiod and the damping ratio of buildings are dependent on the amplitude of vibration. In this paper, these characteristics of the horizontal first mode, based on the seismic observation records obtained from the low and middle raised RC and SRC buildings, are studied. These characteristics are evaluated corresponding to the 2 amplitude levels, the small earthquake level and the middle earthquake level. The observation data are analyzed using the ARX model. The effects of the experience of large earthquakes and aging for each amplitude level are investigated.
\end{abstract}

Keywords: Eigen Period, Damping Ratio, Amplitude Dependency, RC\& SRC Building, ARX model, Horizontal 1st mode 固有周期, 減衰定数, 振幅依存性, $\mathrm{RC} / \mathrm{SRC}$ 建物, $\mathrm{ARX}$ モデル, 水平 1 次モード

\section{1. はじめに}

耐震設計や耐風設計において，固有周期と減衰は応答に大きな影 響を及ぼす重要な要因であるが，今日でも不明な点が多い。特に減 衰については不明確さが大きい。例えば而震設計においては，慣用 的にRC構造では瞬間剛性比例型で3\%, S構造では初期剛性比例型で $2 \%$ 等として用いられているが，その根拠も妥当性も明確ではない。 強震時の応答においてもこれらの設定は応答結果に影響を及ぼす。 従って, 応答解析の精度向上のためには, 小振幅から大振幅に至る までの固有周期や減衰の性状やメカニズムの把握が必須と考える。

建物の固有周期や減衰定数に関寸る振動実測データは，1970年前 後から常時微動測定や振動実験, 地震・風観測により継続的に蓄積 されてきた。1995年の兵庫県南部地震以降は，地盤や建物への地震 計の設置が急速に進み, 観測記録の量も飛躍的に増大した。特に2011 年3月11日の東北地方太平洋沖地震（以下，3.11地震という）では広 範な地域で建物の強震記録が得られた。
これらの分析から，建物の固有周期や減衰定数などの振動特性は, 建物ごとに決まった值ではなく，建物の振幅レベルや入力された振 動数, 更に経年的にも変動する量であり, それに伴って建物の耐震・ 耐風性能も変化することがより明確となってきた。

建築研究所では, 継続的な地震観測によって多数の建物の強震記 録データを蓄積し，研究者に提供している ${ }^{1)}$ 。日本建築学会の建築 物の減衰とその性能評価小委員会・地震時振動特性検討 WG では, このデータに基づく地震時の建物の振動特性の検討を計画している。

本報はその嗃矢として, 中低層の $\mathrm{RC}, \mathrm{SRC}$ 造建物（以下， $\mathrm{RC}$ 系 建物之いう）の水平 1 次の固有周期と減衰定数に着目し検討を行っ たものである。

本報の最大の特徵は, 固有周期と減衰定数の振幅依存性を考慮し て整理した点にある。従来の検討では，様々な振幅レベルでの值が 混在した状態で整理され，振動特性が解りにくくなっている場合も 少なくなかった。そこで本報では，建物の振動特性を微小振幅レ心゙

\footnotetext{
*1 竹中工務店技術研究所 主任研究員 · 博士 (工学)

*2 建築研究所 主任研究員・博士 (工学)

*3 竹中工務店東京本店設計部 博士 (工学)

*4 大和ハウス工業 博士 (工学)

*5 構造計画研究所 博士 (工学)

*6 竹中工務店技術研究所 研究主任 · 修士 (工学)

*7 神奈川大学工学部建築学科 教授·工博

*8 神奈川大学工学部建築学科 助手 $\cdot$ 修士 (工学)
}

Chief Researcher, R\&D Institute, Takenaka Corporation, Dr.Eng.

Senior Research Engineer, Building Research Institute, Dr.Eng.

Building Design Department, Tokyo Main Office, Takenaka Corporation, Dr.Eng.

Daiwahouse Industry, Dr.Eng.

Kozo Keikaku Engineering Inc., Dr.Eng.

Associate Chief Researcher, R\&D Institute, Takenaka Corporation, M.Eng.

Prof., Dept. of Architecture and Building Eng., Kanagawa Univ., Dr.Eng.

Research Assoc., Dept. of Architecture and Building Eng., Kanagawa Univ., M.Eng. 
ルと中振幅レベルに分けて整理し分析を行うこととする。これには 多量のデータが必要となるため, 各建物で観測された全ての地震記 録を用いる。本報の主要な検討項目は以下である。

· 3.11 地震前後の変化

・経験した最大変形角に対する変化

・建物の経年による変化

なお，本報では免震・制振構造は検討から除き， $\mathrm{S}$ 造建物ととも に今後の検討課題とする。また， 2 次以上のモードや，ねじれモー ド，上下モードの分析も今後の課題とする。

\section{2. 建築物の固有周期と減衰に関する近年の知見}

ここでは, $\mathrm{RC}$ 系建物の振動特性, 特に建物の応答性状に影響の大 きな水平 1 次モードに関して近年の研究成果を示す。

(1)，(2)式に，2000 年に出版された「建築物の減衰」 ${ }^{2} に$ 記載され た $\mathrm{RC}$ 建物の微小振幅レベルの水平 1 次固有周期 $\left(T_{I}\right)$ と減衰定数 $\left(h_{I}\right)$ の評価式を適用範囲とともに示す。 $H$ は建物高さ $(\mathrm{m}), x$ は建物頂部 の振幅(m)である。

$T_{I}=0.015 H （$ 適用範囲 $\left.: 10.8 \leqq H \leqq 156.8\right)$

$h_{l}=0.014 / T_{l}+470(x / H)-0.0018$

(適用範囲： $10.8 \leqq H \leqq 129.8 ， x / H \leqq 2 \times 10^{-5}$ )

当時から，建物の固有周期と減衰定数に関して表 1 の特性が知ら れていたが, データの不足から (1), (2)式に反映されたのは下線部の 項目に限られた。

\section{表 $1 \mathrm{RC}$ 系・S 系建物の主要な水平 1 次振動特性}

\begin{tabular}{|c|c|}
\hline 固有周期 & 減衰定数 \\
\hline $\begin{array}{l}\cdot \text { 建物高さに概ね比例する } \\
\cdot \text { 振幅に依存する } \\
\text { ·大地震時に変化する } \\
\cdot \text { 竣工後に経年変化する }\end{array}$ & $\begin{array}{l}\cdot \text { ·振幅に依存する } \\
\cdot \text { ·固有周期に依存する } \\
\text { ·大地震時に変化する（応答が } \\
\text { 大きい場合） }\end{array}$ \\
\hline
\end{tabular}

注）下線は文献 2 の評価式に反映された項目

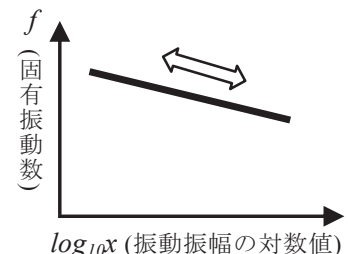

(a) 小地震時

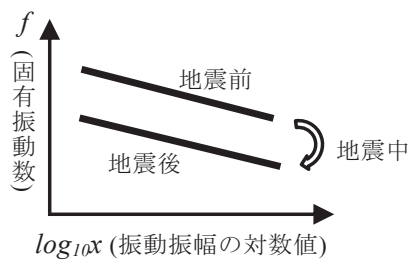

(b) 大地震時
図 1 地震時の振動振幅と固有振動数の変動のイメージ

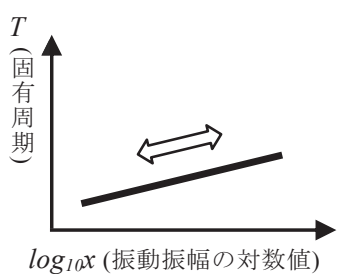

(a) 小地震時

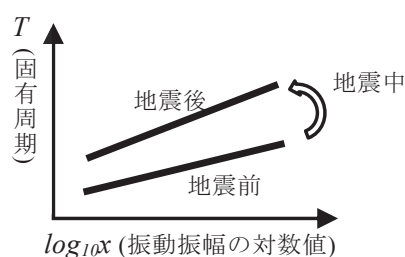

(b) 大地震時
図 2 縱軸を固有周期とした場合のイメージ
その後多数の観測記録が蓄積され，特に 3.11 地震では，広い地域 で強震動が発生し, 多数の建物で強震記録が得られた。これらの分 析より，建物の減衰性能に関して多くの新たな知見が得られた例えは 3 5)。もちろん現時点でもデータは十分とはいえないが, 本報では表 1 の残された項目について検討し，可能な範囲で定量的な評価を試 みるものである。

\section{1 固有周期と減衰の振幅依存性}

建築物の固有振動数（あるいはその逆数の固有周期）は振幅依存 性を有し, 変位, 変形角, 加速度等の振動振幅の対数值に対して概 泴線的に変化する傾向があることが指摘されている。飛田ら ${ }^{6}$ は, 1994 年の三陸はるか沖地震の前後で 3 階建ての RC 造建物の振動性 状を検討し, 固有振動数と振動振幅に関して以下の知見を得た。図 1 にその概念図を示す。

- 小地震では, 固有振動数と振動振幅の対数值の右下りの直線上を 左上から右下に移動し，その線上を戻った。

・大震時には, 主要動付近で顕著な剛性低下を起こし, もとの直線 がループを描く形で下へ平行移動した形になった。

3.11 地震においても同様な事例が多数報告されている。例えば, 千葉県の RC 造 24 階建ての建物 7)では, 同地震により固有周期が大 きく増大し, もとに戻っていない。東京湾岸部の SRC 造 32 階建て の建物においても概放同様の特性 ${ }^{8)}$ を示している。縦軸を固有周期 とした場合は，図 2 のように右上がりの直線となり，大地震時には 上に移動する。このとき, 文献 7, 8 とも固有周期の傾斜がやや増大 する（振幅依存性が増加する）傾向がみられる。

また地震後の減衰定数については, 多くの事例ではあまり変化は 見られない。ただし，建物の応答レベルが大きい場合には減衰定数 が増加する傾向が示されている。文献 7,8 の建物や, つくば市の 8 階建ての SRC 建物 ${ }^{9)}$ では, 3.11 地震での建物の応答が大きく, 地 震後の減衰定数の増加が見られる。

上林ら ${ }^{10)}$ は, 兵庫県南部地震と 3.11 地震で大きな入力を受けた 超高層建物の応答を分析し, RC 系建物で平均層間変形角と減衰定 数に明瞭な関係が見られたと報告している。また文献 8 の建物につ いては, 3.11 地震とその前後の地震について, 地盤建物連成系モデ ルによるシミュレーション解析が行われ ${ }^{11}$, 固有周期と減衰定数の 変化が観測と良好に対応する結果が得られている。

\section{2 固有周期と減衰定数の関係}

構造物の減衰の要因の一つとして, 地盤一建物の動的相互作用, 特に地盤の逸散減衰があり, 特に固有周期の短い中低層の建物にお いて振動の振幅が小さい場合にはその影響が大きく, 1 次固有周期 $T_{1}$ と 1 次の減衰定数 $h_{1}$ の積が一定值となる(3)式の関係 $\left.{ }^{12}\right)$ が示され ている。文献 2 では, 微小歪レベルでの 1 次固有周期に対する $C$ の 值として, RC 系建物では 0.0138 を与えている (図 3 参照)。これは (2)式の右辺の第 1 項の夕を考慮した場合に対応する。

$$
h_{1} T_{1}=C
$$

本会の「建築物の減衰機構とその性能評価小委員会」では, 引き 続きデータの収集を行い, データベースとして蓄積している。2013 
年時点でのデータ ${ }^{13)}$ にれば, $\mathrm{RC}$ 造の $\mathrm{C}$ の值は 0.016 程度となっ ている。

これらの式に対して観測結果と比較した事例も多い。例えば，鹿 嶋ら ${ }^{14}$ は, 2005 年に 25 地点の建物（RC 造 6 棟, SRC 造 13 棟, S 造 6 棟）を対象にして強震観測記録の分析を行っている。これらの 記録から固有周期と減衰定数を同定し $C$ を求めると, $\mathrm{RC}$ 系建物で は 0.01 から 0.02 に分布したとしている。

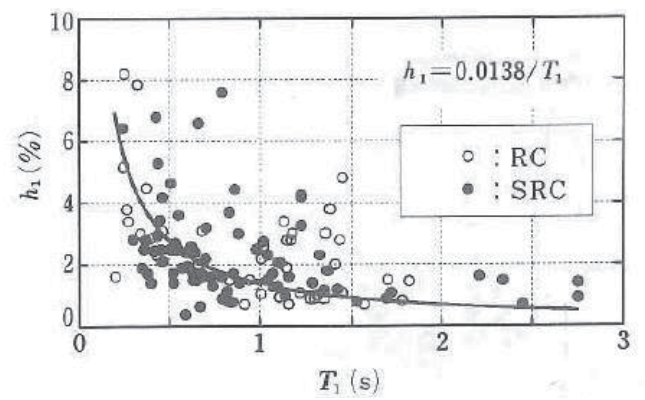

図 $3 \mathrm{RC}$ 造建物の固有周期と減衰定数の関係 ${ }^{2}$

\section{3 固有周期と減衰定数の経年変化}

微動測定や地震観測を長期にわたり継続することで, 振動特性の 経年変化を計測した報告がされている。

森下ら ${ }^{15)}$ は, RC 造 4 階建ての集合住宅の 17 年間の地震記録から, 1 次固有振動数の変化を検討した。また, 文献 9 の建物では, 竣工 から 3.11 地震後までの経年変化が得られている (図 4 参照)。いず れも 1 次振動数は竣工後ゆるやかに低下し, 数年後に安定する傾向 が見られる。鹿嶋ら ${ }^{14)}$ は, この変化の原因として, 中小規模の地震 を繰り返し経験したためとしている。また, 図4 のように3.11 地震 の強震動を受けると, 固有振動数は大きく低下している。

長期にわたる減衰定数の計測結果からは, 固有振動数のような明 確な経年変化を確認できた報告はこれまで少なかった。しかし, 図 4 の建物では 3.11 地震において, 地震後に固有振動数に加えて減衰 定数も明確に変化している。震災により雑壁に多くのひび割れが観 測され，その影響と考えられる。

表 2 検討に用いたデータ

\begin{tabular}{|c|c|c|c|c|c|c|c|c|c|c|c|}
\hline No. & CODE & 所在地 & 種別 & 階数 & $\begin{array}{l}\text { 基礎 } \\
\text { 形式 }\end{array}$ & $\begin{array}{c}\text { 地震計 } \\
\text { 設置位置 }\end{array}$ & $\begin{array}{l}\text { 建設 } \\
\text { 年 }\end{array}$ & 計測期間 & $\begin{array}{l}\text { 記録地 } \\
\text { 震波数 }\end{array}$ & $\begin{array}{c}\text { 頂部加速度 } \\
\text { の最大値 } \\
(\mathrm{Gal})\end{array}$ & $\begin{array}{c}\text { 平均層間変形 } \\
\text { 角の最大値 } \\
\left(\mathrm{x} 10^{-3}\right)\end{array}$ \\
\hline \multirow{2}{*}{1} & \multirow{2}{*}{$\mathrm{HCN}$} & \multirow{2}{*}{$\begin{array}{l}\text { 青森県 } \\
\text { 八戸市 }\end{array}$} & \multirow{2}{*}{$\mathrm{RC}$} & \multirow{2}{*}{$6 \mathrm{~F}+\mathrm{B} 1 \mathrm{~F}+\mathrm{P} 1 \mathrm{~F}$} & \multirow{2}{*}{ 杭 } & \multirow{2}{*}{$\mathrm{B} 1 \mathrm{~F}, \quad 6 \mathrm{~F}$} & \multirow{2}{*}{1980} & \multirow{2}{*}{$1993 / 12 \sim$} & \multirow{2}{*}{213} & 962.6 & 0.83 \\
\hline & & & & & & & & & & 983.2 & 1.90 \\
\hline \multirow{2}{*}{2} & \multirow{2}{*}{ YCY } & \multirow{2}{*}{$\begin{array}{l}\text { 千葉県 } \\
\text { 八千代市 }\end{array}$} & \multirow{2}{*}{$\mathrm{RC}$} & \multirow{2}{*}{$6 \mathrm{~F}+\mathrm{B} 1 \mathrm{~F}+\mathrm{P} 2 \mathrm{~F}$} & \multirow{2}{*}{ 杭 } & \multirow{2}{*}{$\mathrm{B} 1 \mathrm{~F}, \quad 7 \mathrm{~F}$} & \multirow{2}{*}{1976} & \multirow{2}{*}{$1996 / 3 \sim$} & \multirow{2}{*}{30} & 359.3 & 0.58 \\
\hline & & & & & & & & & & 485.9 & 1.00 \\
\hline 3 & NIG & $\begin{array}{l}\text { 新潟県 } \\
\text { 新潟市 }\end{array}$ & $\mathrm{RC}$ & $6 \mathrm{~F}+\mathrm{B} 1 \mathrm{~F}+\mathrm{P} 2 \mathrm{~F}$ & 杭 & $\mathrm{B} 1 \mathrm{~F}, \quad 7 \mathrm{~F}$ & $\begin{array}{l}1958 \\
\text { 以前 }\end{array}$ & $1992 / 2 \sim$ & 53 & 111.1 & 0.16 \\
\hline & & 千葉県 & & & 不明 & & & & & 359.1 & 1.00 \\
\hline 4 & FIND & 船橋市 & $\mathrm{KC}$ & OPTPTH & 下明 & $1 F$, or & 1906 & $1990 / 52$ & 202 & 338.9 & 0.81 \\
\hline 5 & NUT & 埼玉県 & $B C$ & $6 \mathrm{~F}$ & 柿 & $1 \mathrm{~F} \quad 6 \mathrm{~F}$ & 1995 & $1998 / 3 \sim$ & 431 & 322.3 & 0.62 \\
\hline 3 & N11 & 南埼玉郡 & $\pi$ & ${ }_{0}{ }_{1}$ & 饥 & 15, ог & 1993 & $1990 / 8=0$ & 401 & 283.0 & 0.69 \\
\hline 6 & $C U R$ & 千葉県 & SRC & $\mathrm{OF}+\mathrm{P} 1 \mathrm{~F}+\mathrm{P} 1 \mathrm{~F}$ & 不明 & B1F $\quad 8$ F & 1003 & $1006 / 2 \sim$ & 20 & 374.9 & 1.28 \\
\hline & & 静岡県 & & & & & & $1000 / 20$ & & 310.3 & 0.95 \\
\hline 7 & SML & 静岡市 & SRC & $6 \mathrm{H}+\mathrm{PlF}$ & 机 & $1 \mathrm{~F}, 6 \mathrm{~F}$ & 1994 & $1998 / 3 \sim$ & 105 & - & - \\
\hline 8 & UTKK & 東京都 & $\mathrm{SRC}$ & $9 \mathrm{~F}$ & 直接 & $1 \mathrm{~F} \quad 7 \mathrm{Fx} 2$ & 1968 & $1996 / 3 \sim$ & 58 & 180.8 & 0.49 \\
\hline 0 & oin & 文京区 & sNe & $9 \Gamma$ & 旦方女 & $1 \Gamma, \quad T \times \times 2$, & 1900 & $1990 / 5-$ & 50 & 212.0 & 0.65 \\
\hline 0 & JWW & 福島県 & $\mathrm{SRC}$ & $8 \mathrm{~F}+\mathrm{P} 1 \mathrm{~F}+\mathrm{P} 2 \mathrm{~F}$ & 槒 & B1F $\mathrm{OF}$ & 1073 & $1093 / 0 \sim$ & 415 & 578.5 & 2.92 \\
\hline S & $1 \ln n$ & いわき市 & DNC & OT DITTILT & 礼 & DIT, & 1910 & $1990 / 9=$ & 410 & 526.8 & 1.54 \\
\hline 10 & MST & 埼玉県 & SRC & $7 F+B 1 F$ & 不明 & $1 \mathrm{~F} \quad 7 \mathrm{~F}$ & 1983 & $1996 / 3 \sim$ & 270 & 189.6 & 0.26 \\
\hline 10 & MS1 & 三郷市 & DNC & ITTDIT & T用了 & $1 \Gamma, \quad 1 \Gamma$ & 1900 & $1990 / 5=$ & 210 & 219.2 & 0.69 \\
\hline 11 & TDS & 埼玉県 & SRC & $\mathrm{BF}+\mathrm{B} 1 \mathrm{~F}+\mathrm{P} 2 \mathrm{~F}$ & 不明 & B1F $8 \mathrm{~F}$ & 1970 & $1096 / 3 \sim$ & 327 & 424.7 & 1.72 \\
\hline 11 & 1DS & 戸田市 & sKe & $O F+D 1 F+P Z F$ & 下明 & D1F, OГ & 1970 & $1996 / 5=$ & 301 & 531.1 & 1.59 \\
\hline 12 & $A N X$ & 茨城県 & $\mathrm{SBC}$ & $8 \mathrm{~F}+\mathrm{B} 1 \mathrm{~F}$ & 直接 & $\mathrm{B} 1 \mathrm{~F} \times 2,1 \mathrm{~F}, 2 \mathrm{~F} \times 2$ & 1998 & $1998 / 3 \sim$ & 1527 & 596.8 & 2.95 \\
\hline 14 & $\pi N \Lambda$ & つくば市 & DIT & 列 & 回㹡 & $5 \mathrm{~F} \times 2, \quad 8 \mathrm{~F} \times 3$ & 1070 & $1500 \% 0$ & 1021 & 570.1 & 3.22 \\
\hline 13 & ANX-M & 茨城県 & $\mathrm{SBC}$ & $8 \mathrm{~F}+\mathrm{B} 1 \mathrm{~F}$ & 直接 & $\mathrm{B} 1 \mathrm{~F} \quad 5 \mathrm{~F} \quad 8 \mathrm{~F} \times 2$ & 1979 & $1998 / 3 \sim$ & 1527 & 682.0 & 3.20 \\
\hline
\end{tabular}

注) 頂部加速度の最大值および平均層間変形角の最大值欄で，上段はNS 方向，下段は $\mathrm{EW}$ 方向の值を示す。

No. 2, 3 の 7F, No. 9 の $9 \mathrm{~F}$ はペントハウス階を示す。 


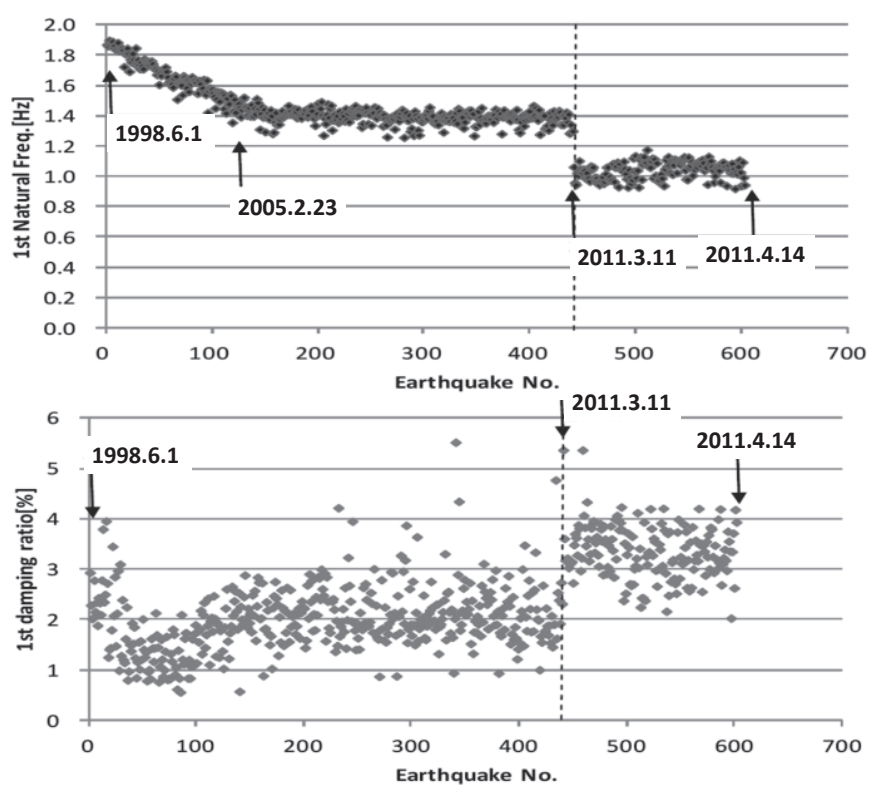

図 4 SRC 造建物の 1 次固有振動数と減衰定数の変化 ${ }^{9)}$

3. 本報における検討の概要

\section{1 検討の概要}

本報では，中低層の $\mathrm{RC} ， \mathrm{SRC}$ 建物の水平 1 次モードに限定し， 固有周期と減衰定数に関する検討を行う。検討に用いたデータを表 2 に示す。いずれも建築研究所から提供されたもので，東日本に建 つ9階建て以下の $\mathrm{RC}$ 系の建物で, 多くが地方自治体の庁舎であり, 全て耐震壁を有するフレーム構造である。免震, 制振を有する建物, 及び観測期間中に耐震改修が行われたものはその影響評価が難しい ため除外することとする。ただしUTKは 2006 年に耐震改修が行わ れているが，その前後で固有周期及び減衰定数の差異がほとんど見 られなかったためデータとして用いることとした。また観測地震記 録数が少ないもの（20 記録以下）も除外する。この結果，検討に用 いられたものは RC5 棟, SRC 8 棟の計 13 棟である。なお，No.12の 建物は，文献 9 と同一のものである。

検討においては，各建物で観測された水平 2 方向（NS 方向に近 い軸と $\mathrm{EW}$ 方向に近い軸の值を，各々 NS，EW 方向と称した）の全 地震記録を対象と寸る。各建物の地震記録数は, 29〜1527 と幅があ る。なお，これらの建物では，固有周期と減衰に関して，NS，EW 方向の值は定性的な傾向が概㸚同様であったため，短辺・長辺での 分類を行わず同列に扱うこととする。また 4.2 節で記すように，本 報では相互作用の影響を分離せず，それを含んだ形で減衰定数を評 価することとする。

\section{2 分析の方法}

本報では, 検討対象を 1 次の水平固有周期と減衰定数に限定する。 多数の地震記録を効率的に分析し，全体としての傾向を把握するた め，比較的簡便な手法とし，以下の手順で行うこととする。検討対 象データとしては, 建物上部階と, 1 階（もしくは地下階）の水平 加速度記録（以下，各々頂部と下部と呼ぶ）を対象とし，NS 方向 と $\mathrm{EW}$ 方向について検討を行う。

(1) 水平 1 次モードの抽出
各建物の NS, EW 方向について, 全ての記録の頂部と下部の観測 加速度時刻歴波形（以下，観測波形という）を振動数領域で除し， 伝達関数を算定する。全ての記録について，1 次モードの形状を漏 らさないように，台形フィルタを目視で設定する。このフィルタを 頂部と下部の観測波形にかけて, 1 次モード近傍に絞ったものとす る。フィルタ形状は，各建物の方向ごとに個別に設定する。

(2) ARX モデルによる固有周期, 減衰定数の同定例えば 16 18)

フィルタ処理した全記録について, 頂部と下部の観測波形を ARX モデル（以下，ARX という）により処理し，1 次固有周期と 1 次減 衰定数を抽出する。ARX の設定は, 継続時間を 20 秒, 分析のピッ チを 5 秒とする。フィルタ処理により 1 自由度系に変換されたもの と考え, モデル化の次数 $\mathrm{N}$ は 2 とする。

(3) 層間変形角の算定

$\mathrm{ARX}$ と並行して，20 秒の同定区間ごとに頂部観測点と下部観測 点の相対変形を求める。区間内で最大の相対変形を頂部と下部の高 さの差で除して平均層間変形角を求める。以下，これを単に変形角 という。

相対変形算定のための頂部と下部の変形の算定においては, フィ ルタ処理を施した加速度記録を積分する。これは相対変形のうち, 1 次モードの変位を抽出することに相当する。比較のため, フィル 夕を施さない観測波形から変形（全モードの変形に相当する）を算 定した。両者を比較したところ, 差異は $1 \%$ 以下となった。これは 検討対象が RC 及び SRC 中低層建物であるため, 頂部と下部の最大 相対変形には 1 次モードが支配的であるためと考えられる。

(4) 変形角による整理

上記で得られた変形角は，多くが $10^{-6}$ から $10^{-3}$ の間にあり，3.11 地震では $10^{-3}$ を超える記録も得られている (表 2 参照)。これらの值 より, 横軸の変形角を対数軸として, 固有周期と減衰定数について, 地震前と地震後の直線近似式を求める。変形角の対数值の 1 次関数 として，固有周期と減衰定数を同定する。

その際，観測地震波を 3.11 地震に関して地震前，地震時（14:46 宮城沖と 15:15 茨城沖の地震記録とする)，地震後で分類する。

各近似直線において, 変形角が $10^{-6}$ と $10^{-3}$ の場合を代表値として 以降の検討を行う。前者は微小地震レベル, 後者は震度 $4 \sim 5$ 弱程度 の地震に対応するものと考える。以降, これらの值を各々微小振幅 レベル，中振幅レベルという。これらに対応する形で， 1 次周期と 減衰定数を整理する。

以上を全建物の NS，EW 方向について実施する。

(5) 経年変化による整理

経年変化を検討する建物については，年毎に地震記録を整理し同 定を行う。

なお，本報で用いている建物の平均層間変形角と，最大となる層 の変形角は差異がある。その比率（最大/平均）は建物により異なり 一概に扱うのは難しい。一例として, 表 2 No.12 の ANXの 3.11 地 震とその前後の地震に対する 1 次モードの分析 ${ }^{19}$ に基づき試算する。 この建物では 2 階床以下の剛性が高いため, 変形は概敉 2 階床から 8 階床の間で平均的に生じている。その高さの比が $1: 2$ 程度である ことから，この建物における上記の比率は 1.5 程度となる。また, 中川ら ${ }^{20)}$ は超高層 $\mathrm{S}$ 造建物に対して 1.1 1.5 の值を示している。 

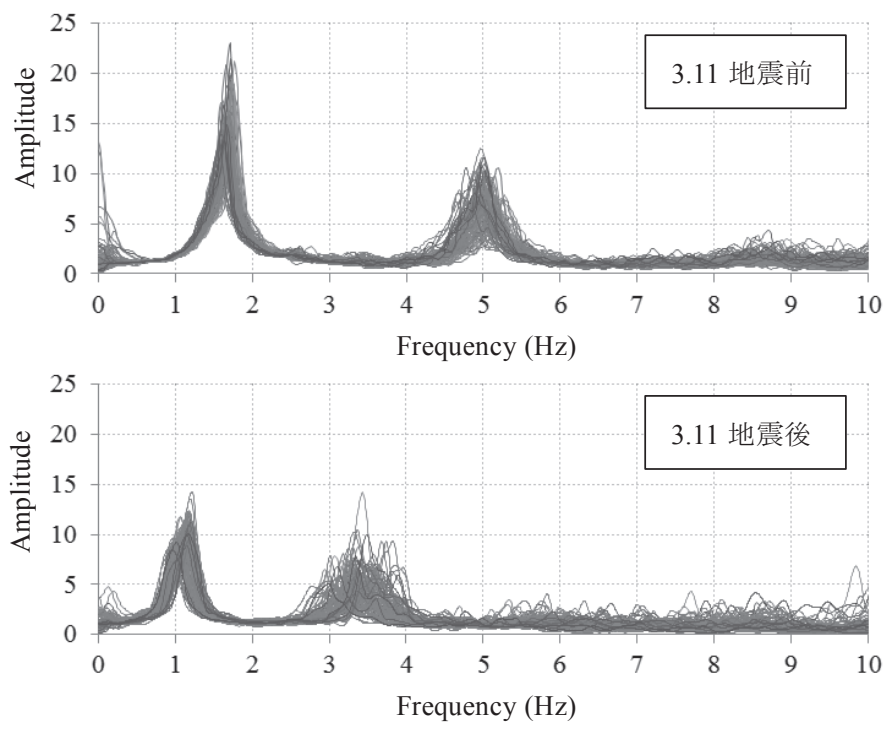

図 5 IWK (NS 方向) の伝達関数

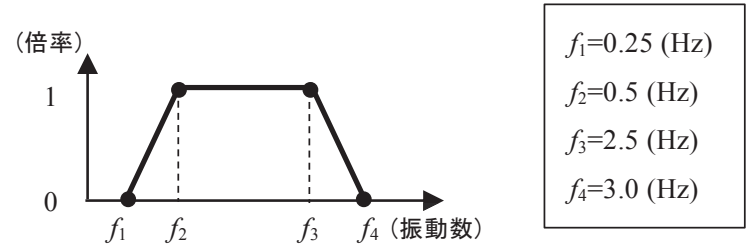

図 6 台形フィルタの設定 $\left(f_{1} \sim f_{4}\right.$ の值は IWK(NS 方向)の場合 $)$

\section{3 算定の事例}

SRC 建物の IWK（表 2 の No.9）の NS 方向を例として, 算定手順 と結果の概要を示す。この建物は SRC 構造 8 階建てで, 地下 1 階, 塔屋 2 階を有している。地下 1 階と屋上階（表 2 中の B $1 \mathrm{~F}$ と $09 \mathrm{~F}$ ) に地震計が設置されている。観測では, 3.11 地震を含む 415 波の記 録が得られている。建物頂部の水平方向最大応答加速度は, 3.11 地 震時の NS 方向で, $578.5 \mathrm{Gal}$ が得られている。加速度を積分して算 定した変形角は $2.87 / 1000 \fallingdotseq 1 / 350$ となっている。図 5 に建物の伝達 関数 $(09 \mathrm{~F} / \mathrm{B} 1 \mathrm{~F})$ を示す。 3.11 地震以前と以後では, 1 次ピークの位 置と高さが変化していることがわかる。この図より, 台形フィルタ を設定する (図 6 参照)。

図 7 に, 頂部で最大加速度を記録した 3.11 地震 (14:46 宮城沖) の ARX 分析結果を示す。地震の継続時間中に固有周期は 0.6 秒から 1.1 秒に変化し，減衰定数はばらつきがあるものの $4 \%$ 程度から $7 \%$ 程度に変化している。

図 8, 図 9 は, 全波形データから得られた IWK, NS 方向の 1 次固 有周期と減衰定数をプロットしたものである。横軸は各区間の平均 変形角 $(r)$ を対数で示す。図 8 の固有周期については, 建物高さ $H$ で除した值(以下， $T_{1} / H$ という)で示す。同図より固有周期は, 3.11

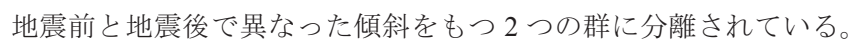
3.11 地震時のデータはその右側に各群をつなぐ形（図中の破線の楕 円）で表れている。また 3.11 地震以前は振幅の対数に対してほぼ直 線的な性状となっている。同地震以後は, やや下に凸な形状となっ ているものの, 直線化しても全体的傾向は失われないと考え, 各群 を直線で回帰し図中の式を得た。決定係数 $\mathrm{R}^{2}$ は各々 0.75 と 0.77 で あり，良好に回帰されているといえる。
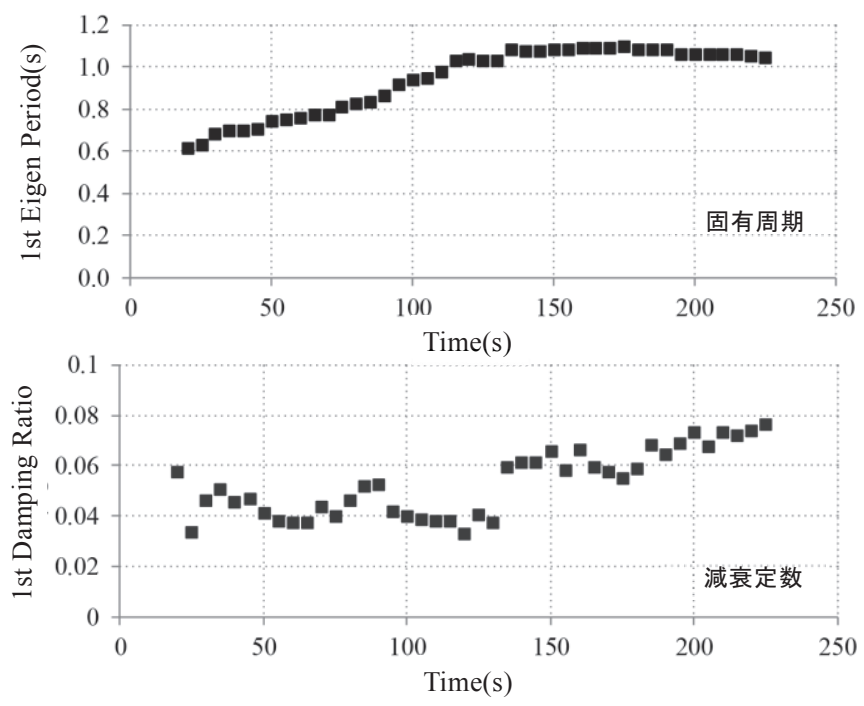

図 7 3.11 地震中の固有周期および減衰定数の変化

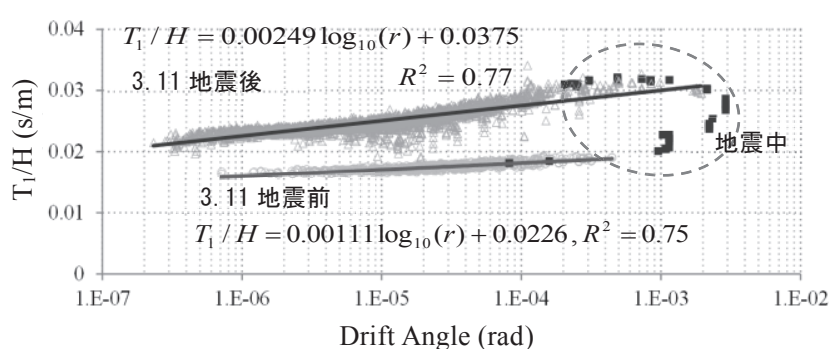

図 8 固有周期 $\left(T_{1} / H\right)$ と変形角 $(r)$ の関係 (IWK, NS 方向 $)$
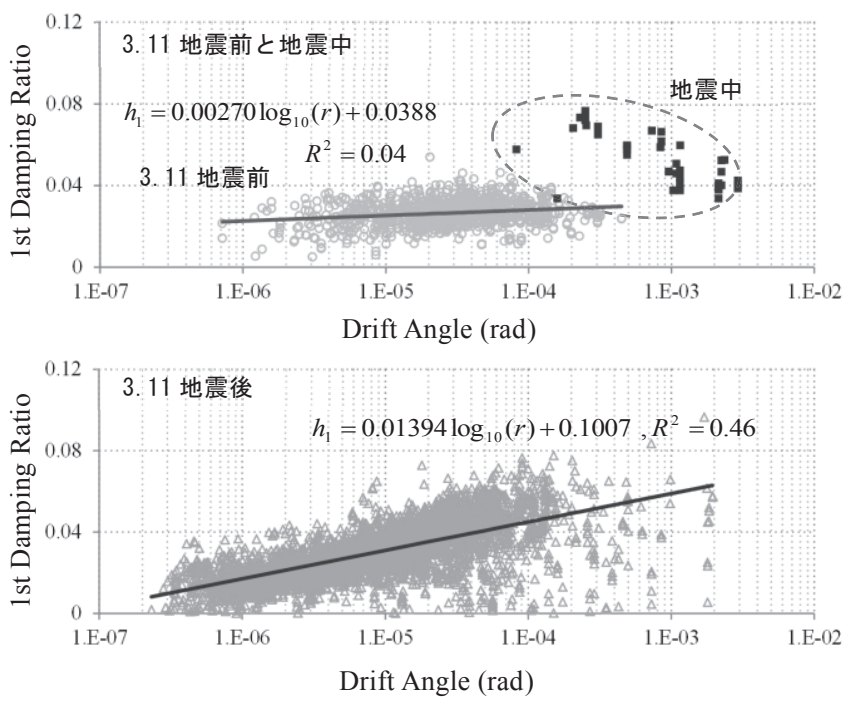

図 9 減衰定数 $\left(h_{1}\right)$ と変形角 $(r)$ の関係 (IWK, NS 方向)

減衰定数では, 固有周期ほど明瞭ではないが， 3.11 地震以前に比 して以後は值と傾斜角が大きくなる傾向が見られる。同様の直線回 帰により図中の式を得た。地震前の $\mathrm{R}^{2}$ は 0.04 と小さな值となって いるが，これは回帰係数が 0.0027 と微小な值であるためと考えられ る。回帰式は，概ね $0.01 \sim 0.04$ の比較的狭い範囲に分布するデータ を貫いており，回帰は概ね良好といえる。 


\section{4. 分析結果}

\section{1 固有周期と減衰定数の振幅依存性}

前章の固有周期と減衰定数の振幅に対する直線回帰を，す心゙ての 建物の NS， EW 方向について行う。これらを RC 建物と $\mathrm{SRC}$ 建物 に分けて整理したものを図 10, 図 11 に示す。各図の左列は 3.11 地 震前, 右列は 3.11 地震後のものである。図中の灰色線は, 各建物の 回帰結果を示している。黒線は, 線両端に丸が付いたものが平均値, 丸印無しの線が $\pm \sigma の$ 值を示している。また，線両端の丸印は，全建 物の線の外端に対応している。

図 11 の右下の図では変形角 $10^{-7}$ 以下で減衰定数が負となっている。 これは，変形角 $10^{-7}$ 付近のデータが負になっていたためではなく， 直線回帰において多数を占める変形角 $10^{-6}$ 以上のデータに影響され たためであり，変形角 $10^{-7}$ 付近の回帰結果の信頼性は低い。このた め前述のように, 微小振幅レベルの代表值は $10^{-6}$ としている。
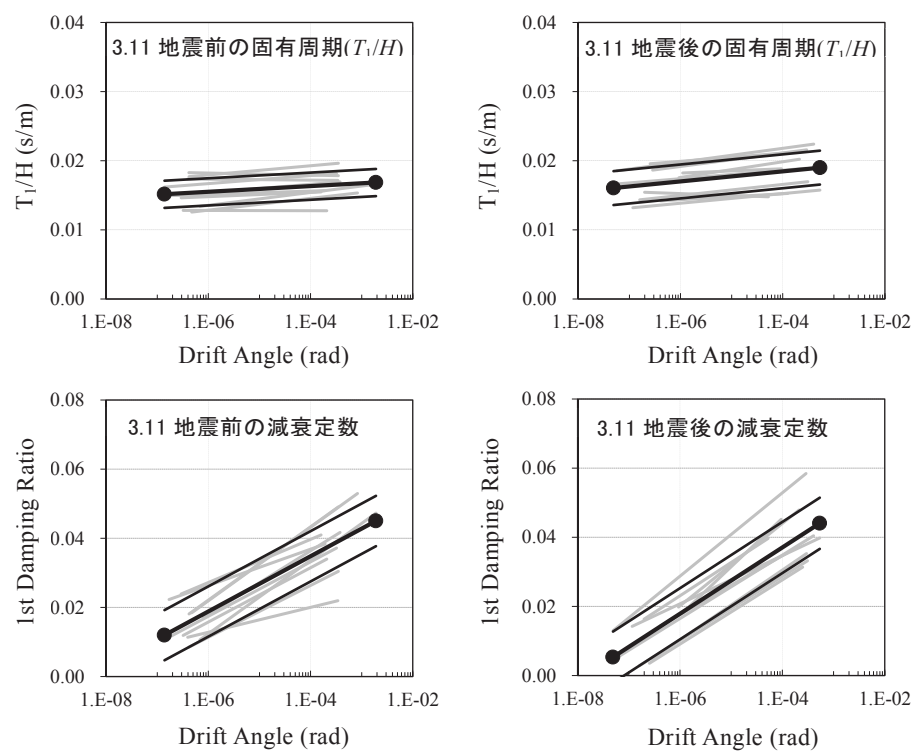

図 $10 \mathrm{RC}$ 建物の固有周期 $\left(\mathrm{T}_{1} / \mathrm{H}\right)$ と減衰定数の振幅依存性
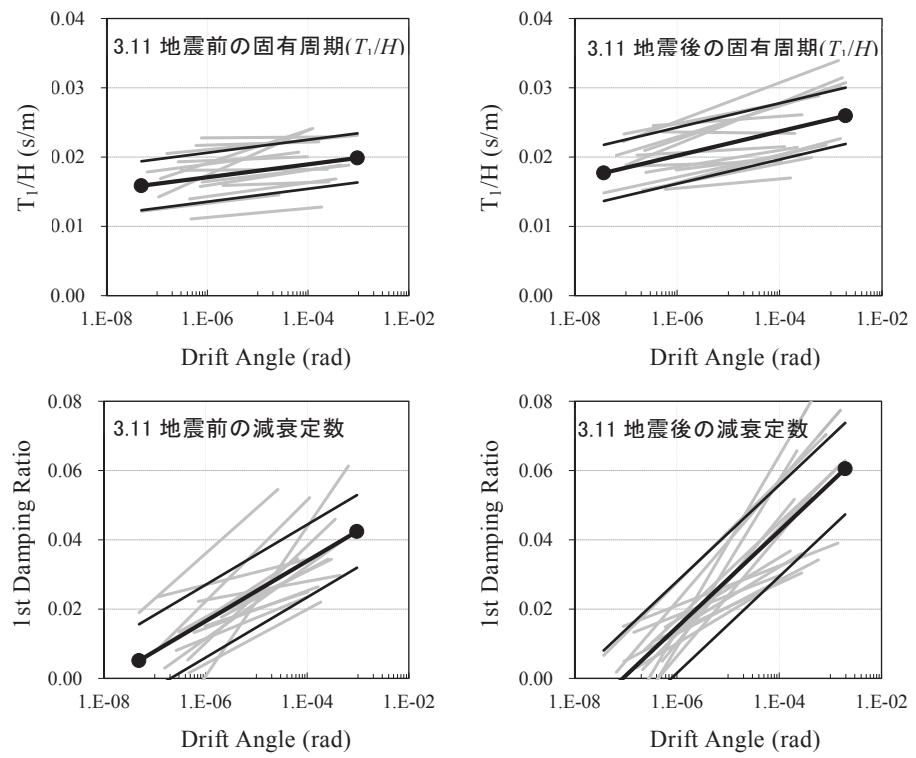

図 11 SRC 建物の固有周期 $\left(T_{1} / H\right)$ と減衰定数の振幅依存性
$\mathrm{RC}$ 建物では，固有周期には緩やかな振幅依存性がみられ，減衰 定数にはより傾きの大きな振幅依存性がみられる。 SRC 建物にも同 様の傾向が見られるが，ややばらつきが大きくなっている。

図 12 , 図 13 にこれらの平均值を 3.11 地震前と後で比較する。 $\mathrm{RC}$ 建物, SRC 建物とも固有周期はやや増大し, 減衰定数の傾きは大き くなる傾向がある。これが 3.11 地震の影響と考えられる。なお $\mathrm{RC}$ 建物より $\mathrm{SRC}$ 建物のほうが，変化が大きくなっているが，これは $\mathrm{SRC}$ 建物に大きな変形角を経験しているものが多かったためと考 えられる（表 2 および後述の図 17 参照）。

表 3 から表 6 に 3.11 地震前後の $\mathrm{RC}$ 建物と $\mathrm{SRC}$ 建物の固有周期と 減衰定数の值を示寸。図 12 より $\mathrm{RC}$ 建物の地震後の変形角は, $10^{-3}$ より小さいため, この值は直線を外挿して求めた。
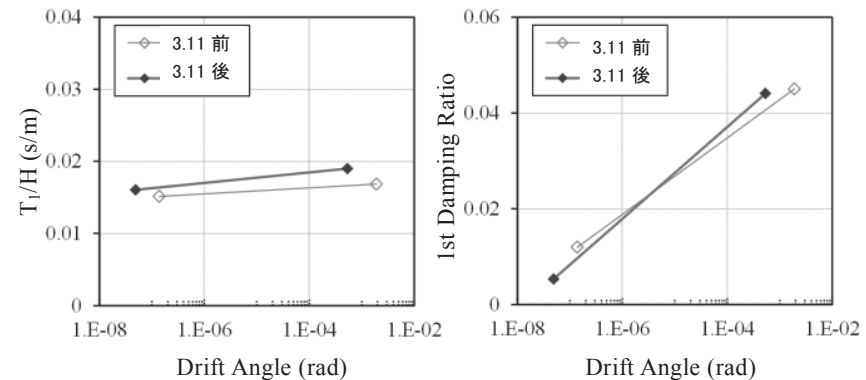

図 123.11 地震前後の $\mathrm{RC}$ 建物の変化
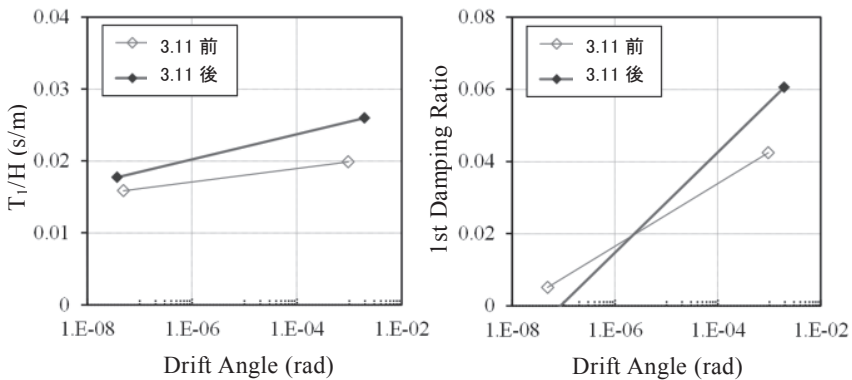

図 133.11 地震前後の SRC 建物の変化

表 3 3. 11 地震前後の $R C$ 建物の固有周期 $\left(T_{1} / H\right)$ の比較

\begin{tabular}{|c|c|c|c|c|l|l|}
\hline & \multicolumn{2}{|c|}{ 微小振幅レベル $\left(10^{-6}\right)$} & \multicolumn{3}{|c|}{ 中振幅レベル $\left(10^{-3}\right)$} \\
\hline & $-\sigma$ & 平均 & $+\sigma$ & $-\sigma$ & 平均 & $+\sigma$ \\
\hline 地震前 & 0.014 & 0.016 & 0.017 & 0.015 & 0.017 & 0.019 \\
\hline 地震後 & 0.015 & 0.017 & 0.019 & 0.017 & 0.019 & 0.022 \\
\hline
\end{tabular}

表 43.11 地震前後の SRC 建物の固有周期 $\left(T_{1} / H\right)$ の比較

\begin{tabular}{|c|l|l|l|l|l|l|}
\hline & \multicolumn{2}{|c|}{ 微小振幅レベル $\left(10^{-6}\right)$} & \multicolumn{3}{|c|}{ 中振幅レベル $\left(10^{-3}\right)$} \\
\hline & $-\sigma$ & 平均 & $+\sigma$ & $-\sigma$ & 平均 & $+\sigma$ \\
\hline 地震前 & 0.014 & 0.017 & 0.021 & 0.016 & 0.020 & 0.023 \\
\hline 地震後 & 0.016 & 0.020 & 0.024 & 0.021 & 0.025 & 0.030 \\
\hline
\end{tabular}

表 $5 \quad 3.11$ 地震前後の RC 建物の減衰定数の比較

\begin{tabular}{|c|c|c|c|c|c|c|}
\hline & \multicolumn{3}{|c|}{ 微小振幅レベル $\left(10^{-6}\right)$} & \multicolumn{3}{|c|}{ 中振幅レベル $\left(10^{-3}\right)$} \\
\hline & $-\sigma$ & 平均 & $+\sigma$ & $-\sigma$ & 平均 & $+\sigma$ \\
\hline 地震前 & 0.012 & 0.019 & 0.026 & 0.036 & 0.043 & 0.050 \\
\hline 地震後 & 0.010 & 0.018 & 0.025 & 0.039 & 0.047 & 0.054 \\
\hline
\end{tabular}

表 63.11 地震前後の SRC 建物の減衰定数の比較

\begin{tabular}{|c|c|l|l|l|l|l|}
\hline & \multicolumn{2}{|c|}{ 微小振幅レベル $\left(10^{-6}\right)$} & \multicolumn{3}{|c|}{ 中振幅レベル $\left(10^{-3}\right)$} \\
\hline & $-\sigma$ & 平均 & $+\sigma$ & $-\sigma$ & 平均 & $+\sigma$ \\
\hline 地震前 & 0.006 & 0.017 & 0.027 & 0.032 & 0.043 & 0.053 \\
\hline 地震後 & 0.002 & 0.015 & 0.028 & 0.043 & 0.057 & 0.070 \\
\hline
\end{tabular}




\section{2 建物高さ, 固有周期と減衰定数の関係}

図 14 に建物高さと固有周期の関係を示す。上段は 3.11 地震前, 下段は 3.11 地震後の值を示す。また, 左列は微小振幅の值，右列は 中振幅の值を示寸。各図において, 白抜き記号は RC, 着色記号は $\mathrm{SRC}$ を示している。いずれの図においても， RC 建物と SRC 建物を 併せて評価した場合，建物の高さと固有周期は概ね比例関係にある といえる。

固有周期は微小振幅の值より中振幅の值のほうがやや長く, また 3.11 地震前より 3.11 地震後のほうがやや長い。ただし RC 建物の高 さが $20 \mathrm{~m}$ から $30 \mathrm{~m}$ の狭い範囲に集中しているため, RC 建物単独で 見た場合には，その関係は明確ではない。

各図中に, $\mathrm{RC}$ 建物と $\mathrm{SRC}$ 建物を併せて建物高さと固有周期を比 例式で回帰した結果を示す。表 3, 表 4 の值と概㸚対応している。
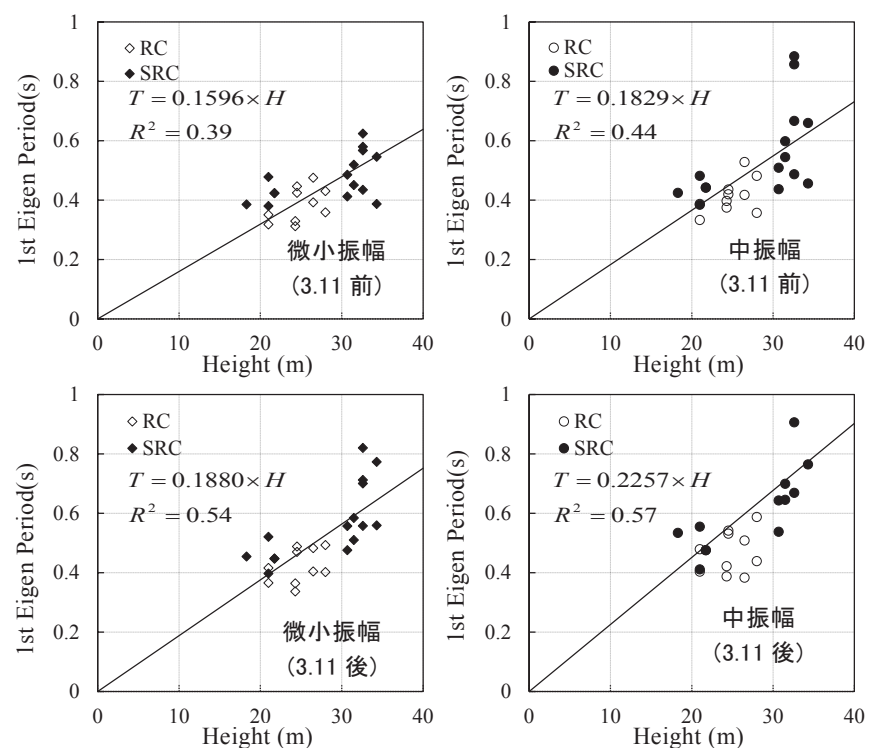

図 14 建物高さと固有周期の関係
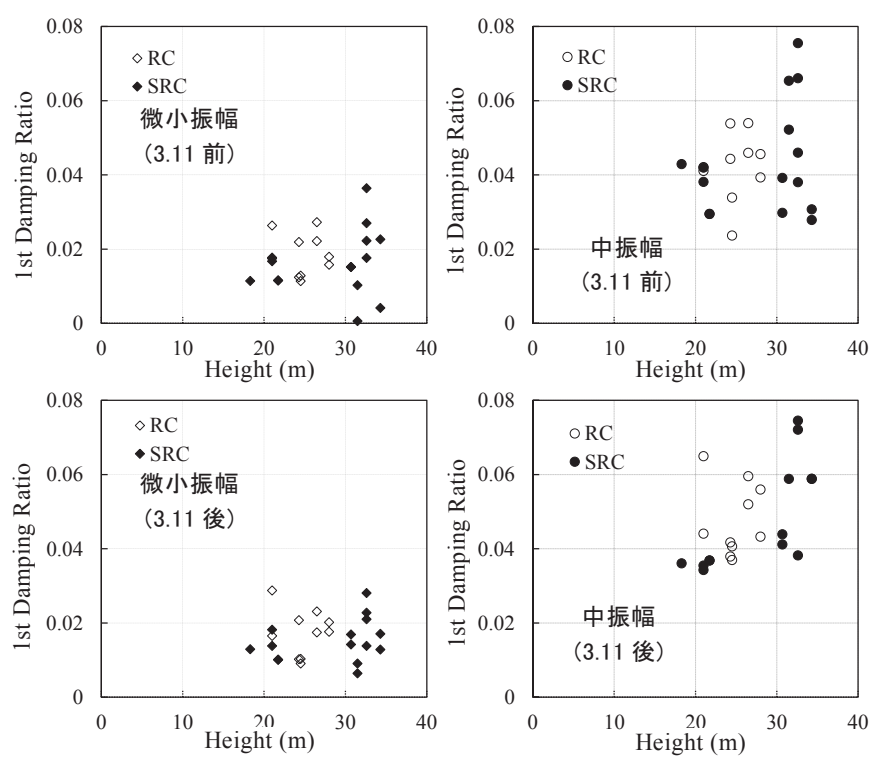

図 15 建物高さと減衰定数の関係
四 15 に建物高さと減衰定数の関係を示す。眓の配置及び白抜き と着色記号の意味は図 14 と同様である。いずれの図においても, 建 物の高さと減衰定数の相関関係は必ずしも明確ではない。減衰定数 は微小振幅の值より中振幅の值のほうが明確に大きい。また 3.11 地 震前と 3.11 地震後の比較では, 微小振幅ではあまり差はなく, 中振 幅では 3.11 地震後のほうがやや大きい。

図 16 に固有周期と減衰定数の関係を示す。図中の曲線は図 3 の $h_{l}=0.014 / T_{l}$ に対応するものである。全体として $T_{l}$ と $h_{1}$ が半比例する 傾向はあまり見られない。これは各建物の高さが概ね $20 \mathrm{~m}$ から $35 \mathrm{~m}$ 程度の間に集まっており，相互作用効果による減衰定数の差異が明 確に現れにくかったためと考えられる。このため本報では，相互作 用の影響を分離せず，それを含んだ形で減衰定数を評価することと する。
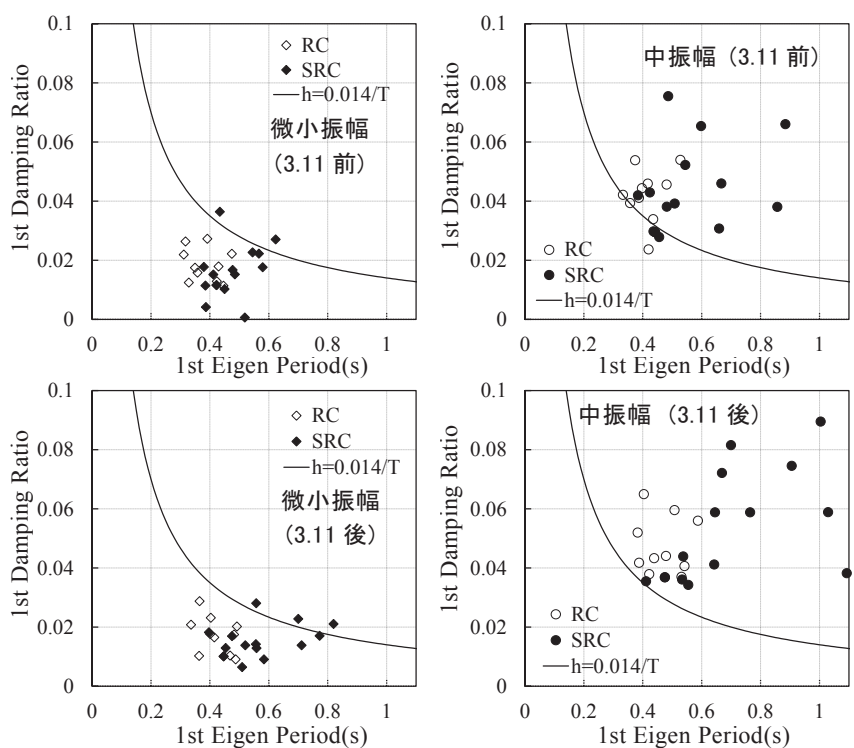

図 16 固有周期と減衰定数の関係
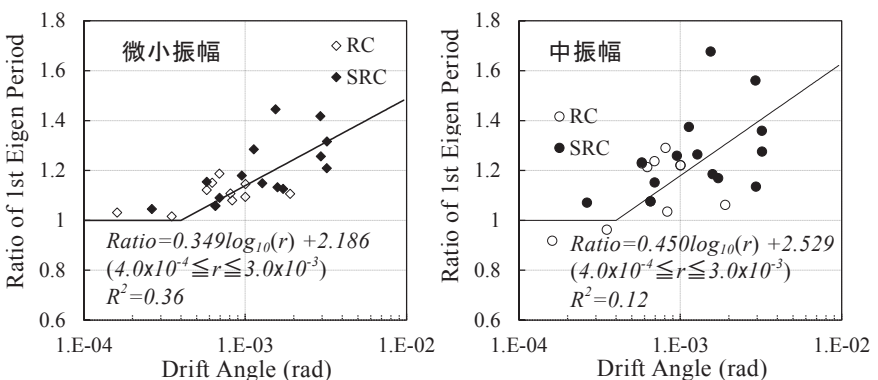

図 173.11 地震での最大の変形角と固有周期の変化率
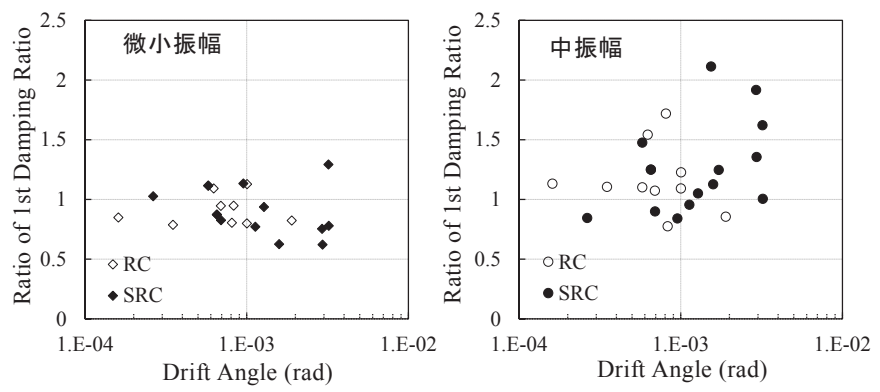

図 18 3.11 地震での最大の変形角と減衰定数の変化率 
微小振幅では, 3.11 地震前と 3.11 地震後とも概ね曲線の下にある。 また 3.11 地震前に比して 3.11 地震後は, 減衰定数はあまり変わらな いものの固有周期が伸びる傾向が見られる。中振幅では, 3.11 地震 前と 3.11 地震後とも概ね曲線の上にある。また 3.11 地震前に比して 3.11 地震後は, 減衰定数も固有周期も増加寸る傾向が見られる。

\section{3 経験した最大変形角と固有周期の変化率}

図 17 は各建物が 3.11 地震で経験した最大の変形角（以下，最大 変形角という）と 3.11 地震前後の固有周期の変化を調べたものであ る。左図に微小振幅レベルの変化率を, 右図に中振幅レベルの変化
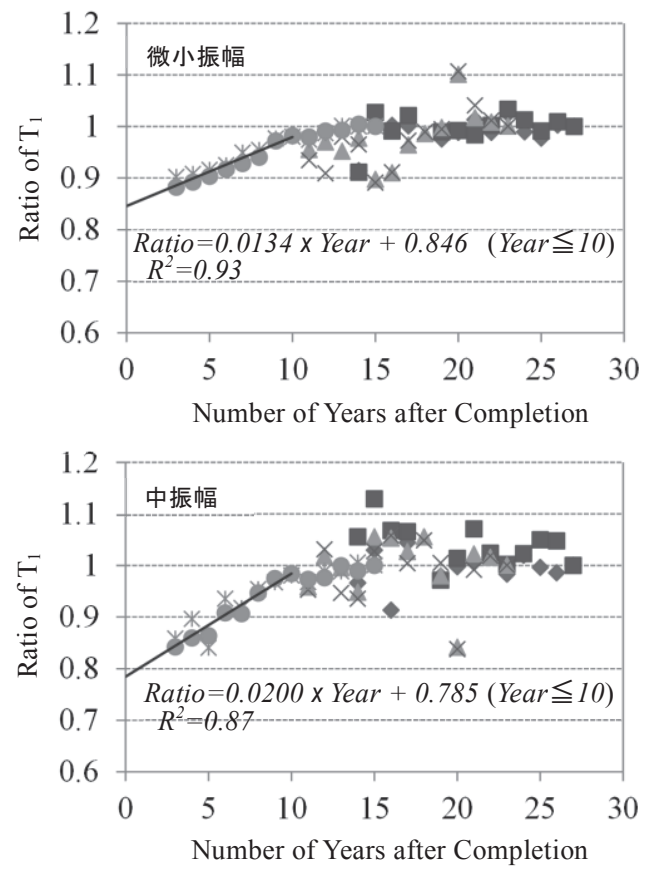

図 $19 \mathrm{RC}$ 建物の固有周期の経年変化

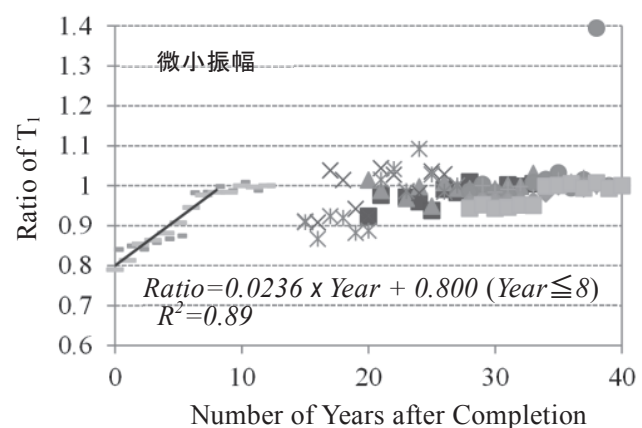

口IWK_(NS) $\triangle$ IWK_(EW) $\times$ MST_(NS) *MST_(EW) -TDS_(NS) +TDS_(EW) -ANX_(NS) - ANX_(EW) $\checkmark$ ANX-M_(NS) aAN-M_(EW)

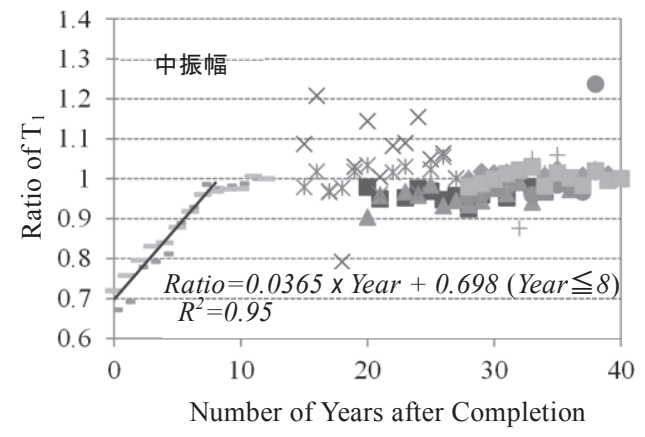

図 20 SRC 建物の固有周期の経年変化
率を示す。いずれの図においてもばらつきは大きいものの, 最大変 形角が比較的小さい場合には縦軸の変化率は 1 に近く, 固有周期の 変化はあまりみられないが, 最大変形角が大きい場合には固有周期 の変化率は増大寸る傾向が現れる。また変化の傾きは，微小振幅レ ベルより中振幅レベルのほうが大きい。

図中の式は，RC 建物と SRC 建物を併せて回帰したものである。 ここでは, 左から 2 個目の白印 (最大変形角 $0.33 \times 10^{-3}, \mathrm{NIG}, \mathrm{NS}$ 方向 $)$ とその右の黒印（同 $0.51 \times 10^{-3}, \mathrm{UTK}, \mathrm{NS}$ 方向）の間で変化の有無が 分かれると考え, その間の值 (同 $\left.0.4 \times 10^{-3}\right)$ に折れ曲がり点を設け, その右側の值を用いて回帰した。上限の変形角は $3.0 \times 10^{-3}$ とした。

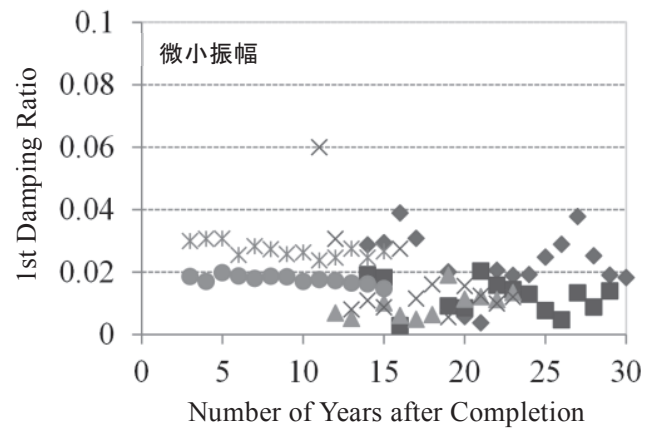

$\bullet$ HCN_(NS)

口HCN_(EW)

$\triangle$ FNB_(NS)

$\times$ FNB_(EW)

*NIT_(NS)

- NIT_(EW)

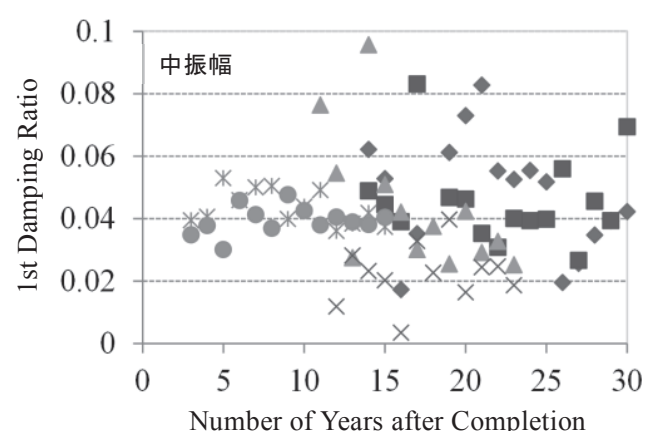

図 $21 \mathrm{RC}$ 建物の減衰定数の経年変化

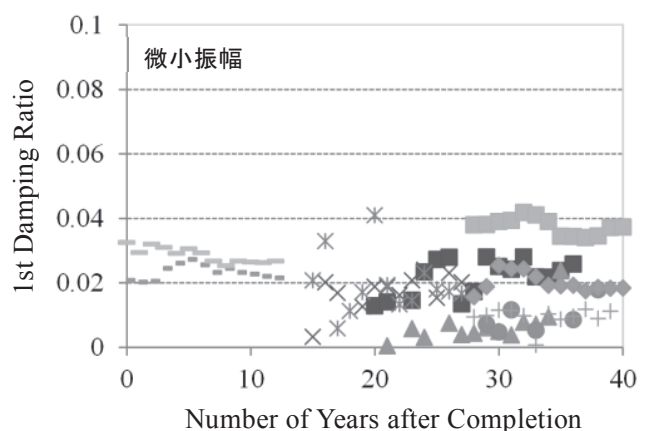

口IWK_(NS) $\triangle \mathrm{IWK} \_(\mathrm{EW})$ $\times$ MST_(NS) *MST_(EW) -TDS_(NS) +TDS_(EW) -ANX_(NS) -ANX_(EW) $\checkmark$ ANX-M_(NS) aNX-M_(EW)

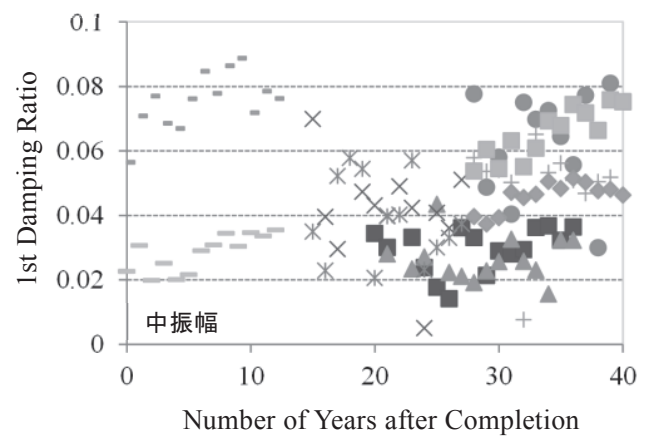

図 22 SRC 建物の減衰定数の経年変化 
図 18 は同様に各建物の最大変形角と 3.11 地震前後の減衰定数の 変化を調べたものである。左図の微小振幅レベルでは, 減衰定数の 変化はほとんど見られないが, 右図の中振幅レベルでは, ばらつき は大きいものの，上記の折れ曲がり点と同様の最大変形角以上で減 衰定数が増大寸る傾向が見られる。

\section{4 固有周期と減衰定数の経年変化}

2.3 節で示したように, RC 系建物の 1 次振動数は竣工後ゆるやか に低下し, 数年後に安定する傾向が見られる。ただし, その後でも 強い震動を受けると, 固有振動数は大きく低下寸る。本節では, 各 建物の観測初期から 3.11 地震前 (最終年を 2010 年とする) までの固 有周期と減衰定数を比較することにより，経年変化に関する検討を 行う。ただし HCN については, 2008 年の地震で震度 6 を記録し, 特性が変化したため, 最終年を 2007 年とする。

各年の固有周期と減衰定数は，図 8〜図 11 で行った固有周期と減 衰定数の平均值を, 年ごとに算定する。そのためには多数の地震波 記録が必要となるため, 表 2 のデータのうち記録地震波数が 200 以 上の建物を用いて検討を行う。

図 19 に $\mathrm{RC}$ 建物の竣工年からの年を横軸とし, 縦軸に固有周期 $\left(T_{1}\right)$ の変化を示す。ただし縦軸には, 最終年の固有周期を 1 とした場合 の，各年の固有周期の比率を示している。

微小振幅レベル, 中振幅レベルとも, 竣工直後の值はないものの, 概ね竣工後 3 年目の観測開始から 10 年までは直線的に増加し, その 後はばらつきが大きいものの概ね一定となっている。竣工後 10 年ま での変化は, 微小振幅レベルより中振幅レベルのほうが大きい。図 中に, 竣工後 10 年までの值を用いて回帰した式を示す。

この式より竣工直後の固有周期を 1 とすれば，竣工後 10 年で安 定した固有周期は微小振幅レベルで 1.18 , 中振幅レベルで 1.27 とな る。同様に, 図 20 に SRC 建物の固有周期の経年変化を示す。この 図では概㱛竣工後 8 年までは直線的に増加し, その後は概ね一定と なっている。竣工後 8 年までの変化は, 中振幅レベルのほうが大き い。

同様に, 図中に竣工後 8 年までの值を用いて回帰した式を示す。 この式より竣工直後の固有周期を 1 とすれば, 竣工後 8 年で安定し た固有周期は微小振幅レベルで 1.25 ，中振幅レベルで 1.43 となる。

以上より, 経年変化に関する定性的な傾向として以下がいえる。 - 竣工後 $8 \sim 10$ 年頃までは, 固有周期は概ね直線的に増加し, その 後は概小一定となる。ただし大地震を受けた場合にはさらに長周 期化する。

・固有周期の変化は, 微小振幅レベルより中振幅レベルのほうが大 きい。この傾向は 3.11 地震を受けた場合の固有周期の変化と対応 する。

ただし $\mathrm{RC}$ 建物， SRC 建物とも固有周期が一定になる前のデータ は, 各々NIT と ANXのみであり, 定量的な評価にはデータは十分 ではない。また, 固有周期の変化の原因が比較的大きな地震の経験 にあるとすれば，建物の立地点に影響されることになる。これらも 含め, さらにデータを収集し検討寸る必要がある。

図 21,22 には RC 建物と SRC 建物の減衰定数の経年変化を示す。 減衰は建物ごとのばらつきが大きいものの全体として経年変化は比 較的小さい。また，これまでの検討と同様に微小振幅レベルより中
振幅レベルの方が大きな值となっており, 前者では $2 \%$ 程度, 後者 では 4\%程度の值となっている。

\section{5. まとめ}

本報では, 3.11 地震を経験した中低層の $\mathrm{RC}$ 系建物について, 多 数の観測地震記録（建物の平均層間変形角 $3 \times 10^{-3}$ 以下）の分析に基 づき, 水平 1 次の固有周期と減衰定数に関して検討を行った。特に, 固有周期と減衰定数の振幅依存性を考慮し，微小振幅レベル（変形 角 $10^{-6}$ 程度）と中振幅レベル（変形角 $10^{-3}$ 程度）に分けて評価を行 った点に特徵がある。得られた主な結果は以下である。

・固有周期には比較的緩やかな振幅依存性がみられ，減衰定数には より傾きの大きな振幅依存性がみられる。

・3.11 地震前の固有周期は $T_{1} / H$ で見ると, 微小振幅レベルで 0.016 〜0.017, 中振幅レベルで $0.017 \sim 0.020$ 程度だった。

• 3.11 地震前の減衰定数は, 微小振幅レベルで $2 \%$ 程度, 中振幅レ ベルで 4\%程度だった。ただしこれは地盤-建物相互作用効果を含 んだ值である。

•3.11 地震では, 固有周期, 減衰定数ともに増加する傾向が見られ た。微小振幅レベルでは固有周期の増加が見られたが減衰定数の 変化は小さかった。中振幅レベルでは微小振幅レベルより変化が 大きく，固有周期，減衰定数ともに増加した。

・経験した最大の変形角が， $4 \times 10^{-4}$ 程度以下の場合固有周期の変化 は小さいが，それ以上の場合は変形角に応じて増大寸る。その変 化は，微小振幅レベルより中振幅レベルの方が大きい。

- 経験した最大の変形角に対して, 微小振幅レベルでは, 減衰定数 の変化はほとんど見られないが，中振幅レベルでは，ばらつきは 大きいものの, $4 \times 10^{-4}$ 程度以上の変形角で減衰定数が増大寸る傾 向が見られた。

- 竣工後 $8 \sim 10$ 年頃までは, 固有周期は経過年月とともに概ね直線 的に増加し，その後は概ね一定となる。ただし大地震を受けた場 合にはさらに長周期化する。

・固有周期の経年変化は, 微小振幅レベルより中振幅レベルのほう が大きい。この傾向は 3.11 地震を受けた場合の固有周期の変化と 対応する。

・減衰の経年変化は比較的小さい。ただし大地震を受けた場合には 増加する。

\section{謝辞}

本検討は, 日本建築学会の建築物の減衰とその性能評価小委員会, 地震時振動特性検討 WG で実施したものである。分析に用いたデー 夕は, 国立研究開発法人建築研究所の強震観測で得られたものであ る。ここに記して謝意を表する。

\section{参考文献}

1) 建築研究所の強震観測: http://smo.kenken.go.jp/ja (参照 2015.12.16)

2) 日本建築学会 : 建築物の減衰, 2000.10

3) 日本建築学会 建築物の減衰小委員会 : 各種建築物の減衰セミナー 評価 手法の比較検討と性能設計一の応用, 日本建築学会, 2004.2

4) 日本建築学会 建築物の減衰と性能設計小委員会：建築物の減衰性能評 価手法の高度化と耐震・耐風設計, 日本建築学会, 2007.11

5) 日本建築学会 建築物の減衰機構とその性能評価小委員会：建築物の減 衰性能とその性能評価に関するシンポジウム資料, 日本建築学会, 2013.3 
6) 飛田潤, 滝田 貢, 毛吕眞, 伊藤敬一: 強地震動による低層 RC 造建物 の振動特性の変化, 構造工学論文集, Vol.45B, pp.73-80, 1999.4

7) 森下真行, 齊藤芳人, 龍神弘明, 渡辺一弘, 田沼毅彦: 長期間の地震観測 記録に基づく $\mathrm{RC}$ 造超高層建物の動特性評価, 日本建築学会大会学術講 演梗概集，構造 II, pp. 695-696, 2012.9

8) 中村充, 勝俣英雄, 福山洋 : 超高層 $\mathrm{RC}$ 建物の地震観測結果に見られる 動特性の振幅依存性, 日本建築学会大会学術講演梗概集, 構造 II, pp.591-592, 2013.8

9) 飯場正紀, 大川出, 斉藤大樹, 森田高市, 長谷川隆 : 平成 23 年 (2011 年) 東北地方太平洋沖地震において観測された強震記録に基づく建築物 の地震挙動の分析, 建築研究所建築研究資料 No138, 2012.9

10) 上林宏敏, 永野正行 : 超高層建物における強震観測記録の応答評価事例 の収集・分析に基づく剛性および減衰特性の統計評価, 日本建築学会大 会学術講演梗概集，構造 II, pp.697-698, 2012.9

11) 中村尚弘, 木下拓也, 石川裕次, 太田博章, 池田周英, 伊藤優, 斎藤大 樹, 福山洋 : 2011 年東北地方太平洋沖地震における超高層 SRC 建物の 地震応答解析, 日本建築学会技術報告集, No. 41, pp 53-58, 2013.2

12) Kobayashi, H: Damping Coefficient of Structural Vibration Related to Subsoil Conditions, 5WCEE, Rome, 1973

13) 佐武直紀 : 各種建築物の減衰データベース, 建築物の減衰性能とその性 能評価に関するシンポジウム, 日本建築学会, 2013.3

14) 鹿嶋俊英, 北川良和: 強震観測記録から推定した建物の振動特性の特徵, 日本建築学会技術報告集，第 22 号，pp.163-166，2005.12

15）森下真行, 斉藤 芳人, 三田彰 : 地震応答に基づく建築構造物の動特性 のシステム同定, 日本建築学会大会学術講演梗概集, 構造 II, pp.123-124, 2010.9

16) Safak, E.: Identification of linear structures using discrete-time filters, Journal of Structural Engineering, Vol. 117, pp.3064-3085, 1991.10

17) 斎藤知生 : モード解析型多入力多出力 ARX モデルを用いた高層建物の システム同定, 日本建築学会構造系論文集 508,pp. 47-54, 1998.6

18) Saito, T. and Beck, J.L.: Bayesian model selection for ARX models and its application to structural health monitoring, Earthquake Engineering and Structural Dynamics, Vol.39, pp.535-547, 2010.12

19) 吉田昂希, 川島学, 永野正行, 鹿嶋俊英, 井口道雄: 2011 年東北地方 太平洋沖地震を経験した中層 SRC 造建物の振動特性の変化, 日本建築 学会大会学術講演梗概集, 構造 II, pp. 545-546, 2012.9

20）中川佳久, 入倉孝次郎, 釜江克宏, 川辺秀憲 : 巨大地震時における長周 期構造物の被害予測, その 2 想定南海地震に対する大阪平野 $\mathrm{S}$ 造超高 層建物の地震危険度マップ, 日本建築学会大会学術講演梗概集, 構造 II, pp. $417-418,2007.7$ 


\title{
STUDY ON HORIZONTAL FIRST MODE VIBRATION CHARACTERISTICS OF LOW AND MIDDLE RISED RC AND SRC BUILDINGS CONSIDERING AMPLITUDE DEPENDENCY
}

\author{
Naohiro NAKAMURA ${ }^{* 1}$, Toshihide KASHIMA*2, Takuya KINOSHITA*3, \\ Shinji ITO ${ }^{* 4}$, Yasushi MIYAMOTO ${ }^{* 5}$, Takayuki SONE*6, \\ Takahisa ENOMOTO ${ }^{* 7}$ and Tetsushi INUBUSHI ${ }^{* 8}$

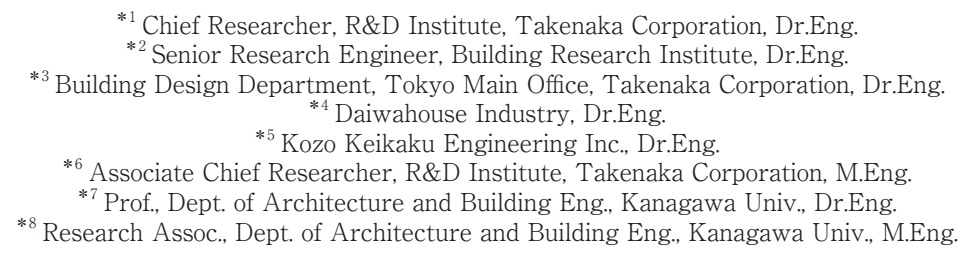

In the structural design of buildings, although the eigenperiod and the damping ratio are very important values which affect on the vibrational behavior of the buildings, the characteristics of them are not understood enough. Recently, many earthquake records of buildings were obtained, especially around the 2011 off the Pacific Coast of Tohoku Earthquake (hereafter the 3.11 earthquake). Based on these records, it becomes well known that the characteristics are dependent on the amplitude of vibration even in the linear condition.

In this paper, these characteristics of the horizontal first mode, based on the seismic observation records obtained from the low and middle raised RC and SRC buildings, are studied. These characteristics are arranged corresponding to the 2 amplitude levels, the small amplitude level (the average drift angle $\mathrm{R}$ is nearly $10^{-6}$ ) and the middle amplitude level ( $\mathrm{R}$ is nearly $10^{-3}$. The observation data, which are obtained by the building research institute for long years, are analyzed using the ARX model.

The obtained main results are as follows.

1) While the small amplitude dependency is seen for the 1st mode eigenperiod, the larger dependency is seen in the $1^{\text {st }}$ mode damping ratio.

2) The $1^{\text {st }}$ mode eigenperiod (shown as $\mathrm{T}_{1} / \mathrm{H}$ ) of buildings before the 3.11 earthquake is nearly 0.016 to 0.017 for the small earthquake level, and nearly 0.017 to 0.020 for the middle earthquake level.

3) The $1^{\text {st }}$ mode damping ratio before the 3.11 earthquake is about $2 \%$ for the small earthquake level, and about $4 \%$ for the middle earthquake level, where the soil-structure interaction effect is included in these values.

4) After the 3.11 earthquake, the values of both the eigenperiod and the damping ratio are increased. The variation of them is larger in the middle amplitude level than in the small earthquake level.

5) When the experienced maximum drift angle is less than $4 \times 10^{-4}$, the variation of the eigenperiod is small. However, when the drift angle is more than that value, the variation becomes larger especially in the middle amplitude level.

6) In the small amplitude level, the variation of the damping ratio is small for the experienced maximum drift angle, while in the middle amplitude level the variation is large when the drift angle is more than $4 \times 10^{-4}$.

7) Concerning to the aging effect, the eigenperiod is continued to be longer until 8 or 10 years after the building completion. After these years, the eigenperiod becomes almost constant. Nevertheless, the eigenperiod becomes longer when the strong earthquake attacked.

8) The variation of the eigenperiod by the aging effect is larger in the middle amplitude level than in the small amplitude level. This tendency is correspond well to that of after the 3.11 earthquake.

9) The variation of the damping ratio by the aging effect is small. However, the damping ratio increases when the strong earthquake attacked. 